\title{
Effects of 3 chemical treatments on in vitro fermentation of rice straw by mixed rumen microbes in the presence or absence of anaerobic rumen fungi
}

\author{
IKO Cann, Y Kobayashi, M Wakita, S Hoshino
}

Faculty of Bioresources, Mie University, Tsu, Mie 514, Japan

(Received 18 August 1993; accepted 16 November 1993)

\begin{abstract}
Summary - Rice straw (Rs) was treated by a sodium chlorite/acetic acid mixture (Sct), ammoniation (At) and alkaline hydrogen peroxide (Athp) methods. The objective was to compare their degradation and fermentation products in the presence or suppression of anaerobic fungi. Significant differences $(P<0.01)$ in degradation of straws were observed during all periods of incubation with Sct having the highest digestibilities during the 48-h and 72-h incubations. The degradation of Sct straw was highest in both of the incubations with whole rumen fluid (WRF) and WRF plus cycloheximide. In sacco digestion followed the order of Sct $>$ At $>$ Rs $>$ Athp. Suppressing fungal activity with cycloheximide resulted in a decrease in dry matter degradation, with concomitant decrease in total volatile fatty-acid concentration. While the suppression of fungal activity with cycloheximide depressed acetate and butyrate production, it favored an increase in propionate production.
\end{abstract}

rice straw / rumen microbe / cycloheximide / fermentation

Résumé - Effet de 3 traitements chimiques sur la fermentation in vitro de la paille de riz par les microbes du rumen, en présence ou après suppression des champignons anaérobies. L'objectif de cette étude était de comparer la dégradation et les produits de fermentation, en présence ou après suppression des champignons anérobies, de la paille de riz (Rs) traitée par un mélange de chlorite de sodium et d'acide acétique (Sct), par ammoniation (At) ou par traitement alcalin au peroxyde d'hydrogène (Athp). Des différences significatives $(\mathrm{P}<0,01)$ de dégradation des pailles ont été observées pendant toutes les péricdes d'incubation, le produit Sct ayant les digestibilités les plus élevées pendant les incubations de 48 et $72 \mathrm{~h}$. La dégradation de la paille Sct était la plus forte dans les 2 incubations, avec du fluide total du rumen sans (WRF) ou avec cycloheximide. La digestion in sacco suivait l'ordre suivant: Sct $>$ At $>$ Rs $>$ Athp. La suppression de l'activité fongique par addition de cycloheximide conduisait à une diminution de la dégradation de la matière sèche, avec une baisse concomitante de la concentration en acides gras volatils totaux. Alors que la suppression de l'activité fongique diminuait la production d'acétate et de butyrate, elle favorisait l'augmentation de la production de propionate.

paille de riz / microbe du rumen / cycloheximide / fermentation 


\section{INTRODUCTION}

The utilization of the lignocellulosic materials abound in nature by ruminants is carried out by a host of microorganisms (bacteria, protozoa and fungi) present in the rumen that ferment these materials yielding mainly acetate, propionate and butyrate. These fermentation products are absorbed and serve as the main energy source for the ruminant. The degradation of these fibrous materials by the microorganisms is, however, constricted by their high lignin content. Chemical treatments, such as chlorite delignification, have been used as means of circumventing this limitation. In recent studies, Elliot et al (1987) and Cann et al (1993b) observed that treatment with sodium chloride/acetic acid mixture (Sct) decreased lignin content but also drastically depressed intake by sheep. This reduced intake of Sct-chaffed barley straw has been attributed to the fungicidal effect of the treated straw (Elliot et al, 1987). However, it has been reported by Windham and Akin (1984) that suppressing fungal activity in vitro did not decrease dry matter degradation of ground alfalfa and coastal bermuda grass.

To investigate the discrepancy, an experiment was conducted to assess the effect of sodium chlorite/acetic acid mixture treatment of rice straw on its degradability by mixed rumen bacteria. The degradability of this material was also compared with ammoniated rice straw and alkaline hydrogen peroxide treatment in the presence or absence of rumen fungi.

\section{MATERIALS AND METHODS}

\section{Substrates}

Rice straw (Rs) was treated chemically by 3 methods, namely, ammoniation at $3 \mathrm{~g} \mathrm{NH}_{3} / 100$ g DM (At) (Cann et al, 1991), alkaline hydrogen peroxide treatment (Athp) (Lewis et al, 1988) and sodium chlorite/acetic acid mixture treatment (Elliot et al, 1987). During Athp treatment, $\mathrm{NH}_{4} \mathrm{OH}$ was used as the alkali instead of $\mathrm{NaOH}$. The treated straws were ground through a $1-\mathrm{mm}$ screen in a Wiley mill and used as substrates.

\section{Substrate characteristics}

Dry matter (DM), neutral detergent fiber (NDF), acid detergent fiber (ADF), hemicellulose, cellulose, lignin and ash were determined as described elsewhere (Cann et al, 1991). X-ray diffraction was performed with a Mini Flex X-ray diffractometer (Rigaku-denki $\mathrm{Co}$ ), operated under the following conditions: X-ray tube $30 \mathrm{kV}$, $10 \mathrm{~mA}$; scanning speed $2 \% \mathrm{~min}$; divergence slit $1^{\circ}$; receiving slit $0.3 \mathrm{~mm}$; time constant $2 \mathrm{~s}$; irradiation CuK $\alpha$, eliminating $\mathrm{K} \beta$ with an Ni-filter.

\section{Microbial inoculum}

Two sheep cannulated in the rumen and maintained daily on $600 \mathrm{~g}$ of alfalfa hay cubes and $200 \mathrm{~g}$ of a commercial formula feed (a grain and mineral supplement, crude protein $12 \%$, total digestible nutrients (TDN) $72 \%$ ) for beef cattle were used as donors of rumen fluid. Rumen fluid $200 \mathrm{ml} / \mathrm{sheep}$ was removed just before offering the morning feed $(9.00 \mathrm{am})$, mixed together and squeezed through 4 layers of surgical gauze. The strained fluid was mixed with a pre-heated $\left(39^{\circ} \mathrm{C}\right)$ McDougall's buffer (McDougall, 1948) in a ratio of $1: 2$ and used as inoculum (WRF). The microbial characteristics (table I) of the rumen fluid were determined as described previously (Cann et al, 1993c).

\section{In vitro studies}

Substrates of weight $0.5 \mathrm{~g}$ from the respective straws (Rs, At, Athp and Sct) were weighed into $70 \mathrm{ml}$ bottles with 4 replicates per sample. The bottles were flushed with an oxygen-free $\mathrm{CO}_{2}$, prepared by passage through a column of heated copper filings, for $2 \mathrm{~min}$ and $25 \mathrm{ml}$ of inoculum (WRF) dispensed into each of the bottles and sealed under anaerobic conditions. To sup- 
press fungal growth, $3 \mathrm{ml}$ of cycloheximide (C6255 , Sigma) solution $\left(5 \mathrm{mg} / \mathrm{ml}\right.$ of distilled $\mathrm{H}_{2} \mathrm{O}$ ) was dispensed together with inoculum (4 replicates per sample) to study the effect of fungal suppression on the degradability and fermentation pattern of the treated and untreated straws The tubes receiving only whole rumen fluid (WRF) received additional $3 \mathrm{ml}$ distilled water to bring their volume to that of the experiment with WRF plus cycloheximide $(B+P$ : the inoculum consists essentially of bacteria (B) and protozoa (P)). Inoculum blanks were prepared to correct for the indigestible dry matter from inoculum residue. In addition, substrates were incubated with only McDougall's buffer (solubility in buffer: At > Rs $>$ Athp $>$ Sct) to correct for solubilization due to the buffer. The incubation was carried out in a water bath at $39^{\circ} \mathrm{C}$ for $12,24,48$ and $72 \mathrm{~h}$. After incubation, samples were filtered (Soseni teiryoroshi C-7000, Sanshin Kogyo, Japan) and the $\mathrm{pH}$ of the fluid determined immediately. The undigested material was washed with $100 \mathrm{ml}$ boiling water and dried at $100^{\circ} \mathrm{C}$ overnight in an oven. The fluid content was stored on mercuric chloride in a freezer at $-4^{\circ} \mathrm{C}$ until analyzed for ammonia nitrogen and volatile fatty acids by colorimetry and gas chromatography, respectively, as described elsewhere (Cann et al, 1991).

\section{In sacco study}

In this investigation, $0.5 \mathrm{~g}$ of each sample was weighed into a nylon bag with pore size $5 \mu \mathrm{m}$.
Samples were then incubated in the rumen of the sheep donating the rumen digesta for the in vitro experiment, in a random fashion, over the periods stated above. After withdrawal, the nylon bags were washed gently with distilled water and the digestibility determined as described in the in vitro study.

\section{Statistical analysis}

The results were analyzed by analysis of variance and Duncan's multiple range test (DMRT) used to separate the means (Duncan, 1955).

\section{RESULTS}

The treatments involving washing (Athp and Sct) in the present experiment significantly $(P<0.01)$ increased NDF with a further increase being observed in ADF content of Athp (table II). An increase in cellulose was observed for Athp and Sct. Lignin content decreased in At and Sct with the most significant $(P<0.01)$ decrease occurring in the latter. The ash content of Athp was significantly $(P<0.01)$ higher compared to the other straws. The X-ray diffraction patterns (fig 1) showed a relative increase in the broad peak be-

Table I. Microbial characteristics of rumen fluid from sheep used for the present experiment. 
tween $19-26^{\circ}$ for Athp and Sct. The microbial characteristics (table I) indicated a total viable count, fungal count and total protozoal counts of $3.7 \times 10^{8}, 1.4 \times 10^{3}$ and $2.6 \times 10^{5}$, respectively. The dominant protozoal species belonged to the genus Entodinum. Digesting the straws with WRF for $12 \mathrm{~h}$ did not show any difference for Sct and Athp digestibilities, but resulted in significantly higher values for At and Rs. The digestibilities during the 24, 48 and $72 \mathrm{~h}$ periods indicated higher $(P<0.01)$ values for the treated straws (Sct, At and Athp) compared with Rs (fig 2a), with Sct showing the highest digestibility followed by At. Compared with WRF, suppressing fungal activity with cycloheximide (fig $2 b$ ) did not result in changes in digestibility values during the 12-h and 24-h incubations. The digestibilities during the 48-h and 72- $h$ periods, however, showed a decreased trend. The digestibility patterns among treatments were, however, similar to that with WRF. The results from in sacco digestion showed an identical pattern to that of

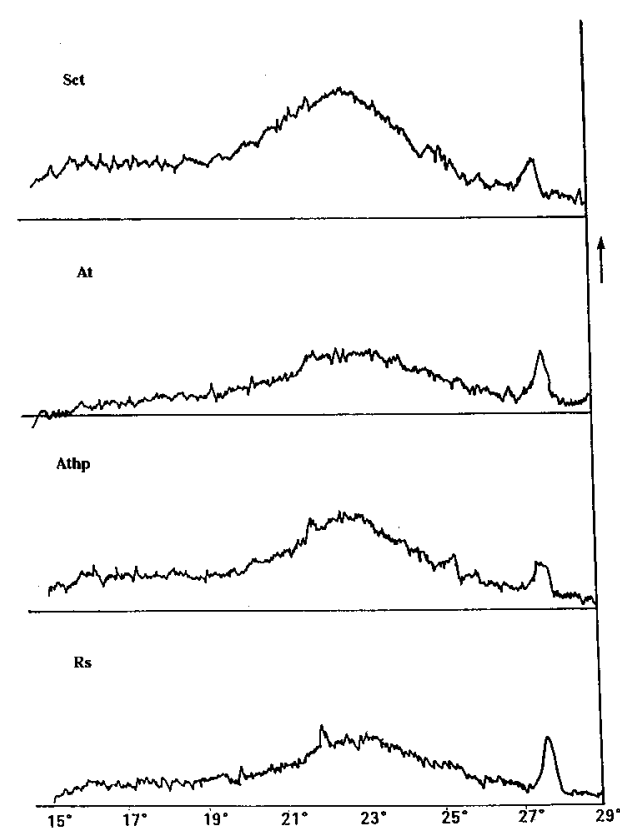

Fig 1. X-ray diffraction patterns of rice straw and treated rice straw. The abscissa is intensity and the ordinate is the angle of diffraction $2 v$.

Table II. Chemical analyses of treated and untreated straws (\%).

\begin{tabular}{|c|c|c|c|c|}
\hline Item & Rs & At & Athp & Sct \\
\hline DM & $88.1 \pm 0.2 \mathrm{a}$ & $88.1 \pm 0.2^{a}$ & $90.2 \pm 0.3^{c}$ & $89.2 \pm 0.2^{b}$ \\
\hline NDF & $74.9 \pm 0.4 \mathrm{a}$ & $76.2 \pm 0.9$ ab & $82.1 \pm 0.2^{c}$ & $77.5 \pm 0.1 b$ \\
\hline ADF & $48.9 \pm 0.3 \mathrm{a}$ & $48.9 \pm 0.2 \mathrm{a}$ & $53.1 \pm 0.5^{b}$ & $49.2 \pm 0.3^{\mathrm{a}}$ \\
\hline Hemicellulose & $26.0 \pm 0.9$ & $27.3 \pm 1.7$ & $29.0 \pm 0.8$ & $28.3 \pm 0.5$ \\
\hline Cellulose & $34.0 \pm 0.1$ a & $34.1 \pm 0.1 \mathrm{a}$ & $37.7 \pm 0.3^{b}$ & $38.6 \pm 0.2^{c}$ \\
\hline Lignin & $6.8 \pm 0.3^{b}$ & $6.1 \pm 0.2^{c}$ & $6.6 \pm 0.2^{b}$ & $2.7 \pm 0.3^{a}$ \\
\hline Ash & $8.1 \pm 0.1 \mathrm{a}$ & $8.6 \pm 0.2 a b$ & $8.8 \pm 0.3^{b}$ & $8.0 \pm 0.1 \mathrm{a}$ \\
\hline
\end{tabular}

Rs: untreated rice straw; At: ammoniated rice straw; Athp: alkaline hydrogen peroxide-treated rice straw; Sct: sodium chlorite/acetic acid mixture-treated rice straw; values are means $(n=4) \pm S E$; means within the same row with different letters differ (Duncan's multiple range test, $P<0.01$ ). 
a: In vitro with WRF

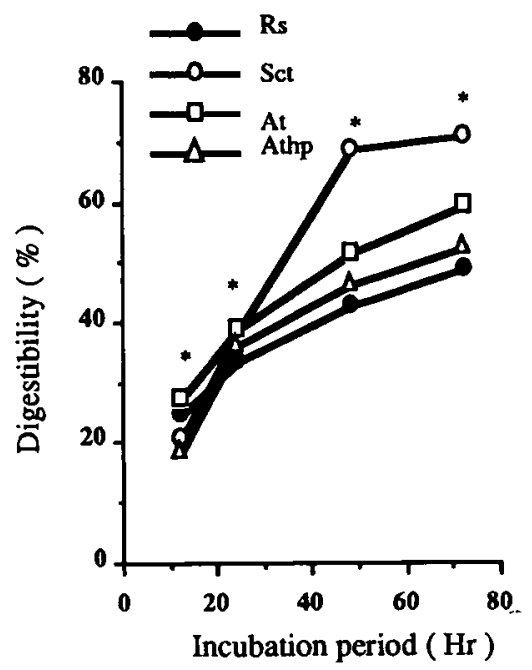

c: In sacco

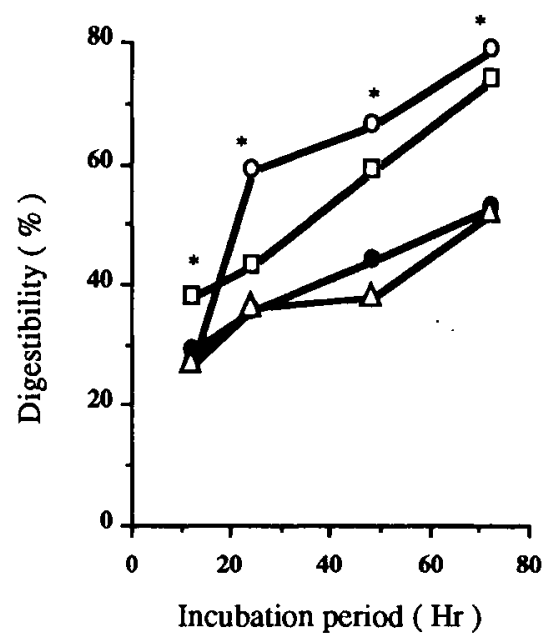

the in vitro experiment, but the digestibilities were higher in sacco than in vitro, especially for Sct and At (fig 2c). The yield of total volatile fatty acids during the fermentation followed the pattern observed for digestion (fig 3 ). The total volatile fatty-acid concentration was highest $(P<0.01)$ during the 48-h and 72-h incubation for Sct. b: In vitro with $\mathrm{B}+\mathrm{P}$

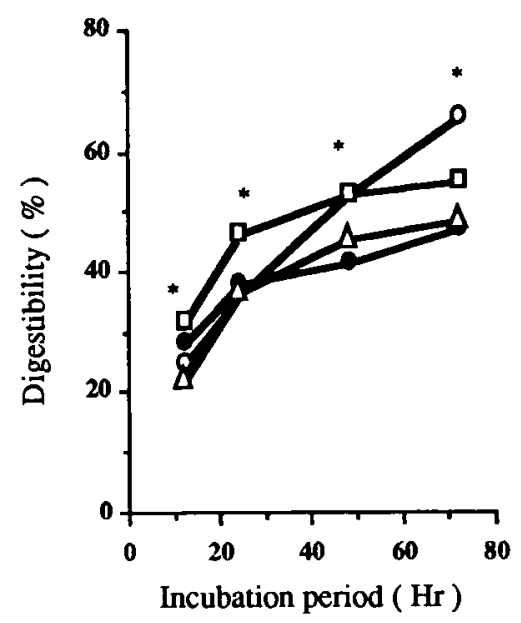

Fig 2. Dry matter digestibilities in vitro (WRF and $B+P)$ and in sacco of chemically treated rice straw. WRF: Whole rumen fluid; $B+P$ : bacteria plus protozoa $=W R F$ in the presence of cycloheximide; " DMRT, $P<0.01$.

The values for Athp and Rs were statistically similar. In all experiments with WRF, acetate proportions due to Sct were significantly $(P<0.01)$ lower compared to the other treatments (At and Athp) and Rs (table III). As the period of incubation increased, acetate proportion decreased, a tendency that was also observed during 
a: In vitro with WRF

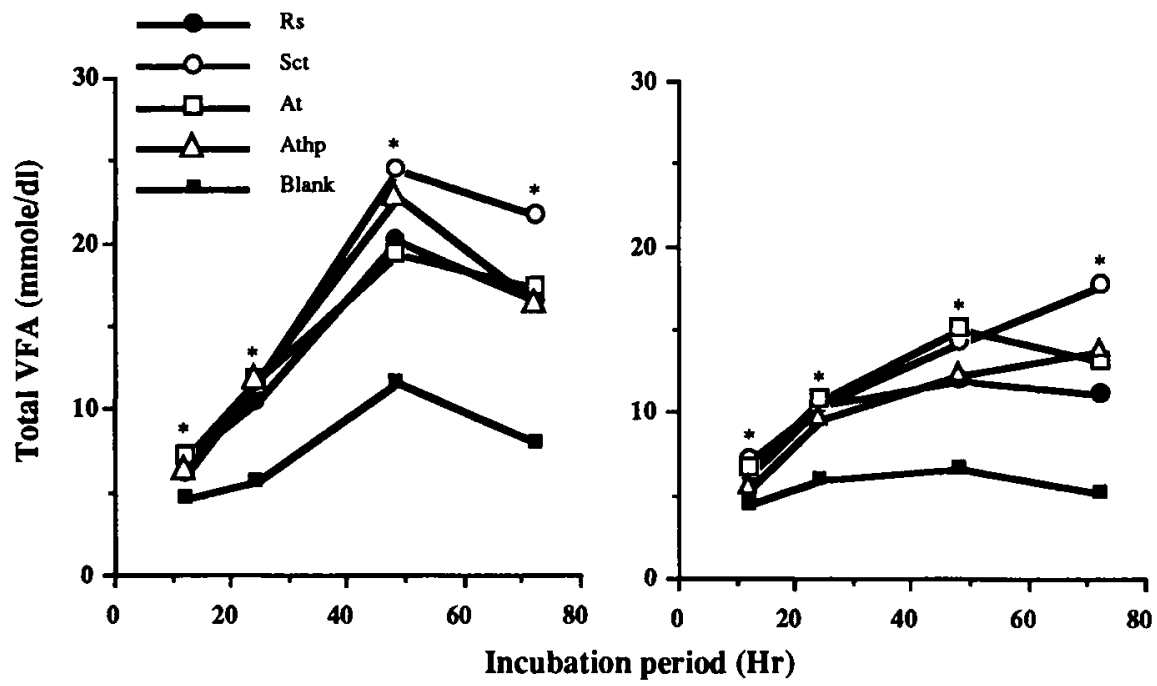

Fig 3. Total volatile fatty-acid concentrations from treated and untreated rice straws incubated with WRF or $B+P$. WRF: whole rumen fluid; $B+P$ : bacteria plus protozoa $=W R F$ in the presence of cycloheximide; ' DMRT, $P<0.01$.

cycloheximide inhibition $(B+P)$ (table IV). The reverse of this trend was noted for propionate proportions. However, the propionate proportions during fungal suppression $(B+P)$ were higher than those of WRF, resulting in decreased acetate/ propionate ratios in all incubations with $(B+P)$. In Sct, the ratio decreased below 1.0 during the 48-h and 72-h incubations for both WRF and $(B+P)$ (table III and IV). The proportion of $n$-butyrate and $i$-valerate were higher in WRF than $(B+P)$, with the values being highest $(P<0.01)$ in Rs. The values for $n$-valerate in the present experiment were not altered $(P>0.05)$ due to treatment. Ammonia $\mathrm{N}$ concentrations were higher during digestion with WRF than $(B+P)$. The values in both cases were highest in At with Sct having the lowest concentration. The $\mathrm{pH}$ values observed for Rs, At and Athp were slightly higher during $(B+P)$ incubation than for WRF. The values for Sct decreased sharp- ly from the 24-h incubation and continued to the 72-h incubation. This observation was made in both WRF and $(B+P)$ incubations.

\section{DISCUSSION}

The treatments involving oxidation and washing (Athp and Sct) in the present experiment with a higher NDF indicated that the treatments removed substantial components of straw normally solubilized during NDF solution extraction. A similar explanation can be offered for the increase in ADF in Athp. The 2 treatments, however, increased cellulose fractions. The increase in the intensity of the broad peak observed in Athp and Sct (fig 1) may reflect the relative increase in the cellulose content due to the 2 treatments. The increases in NDF and ADF proportions observed for Athp were also obtained by other workers using 
Table III. Fermentation products, $\mathrm{pH}$ and $\mathrm{NH}_{3}-\mathrm{N}$ concentrations of treated and untreated rice straw with whole rumen fluid (WRF) in vitro*.

\begin{tabular}{|c|c|c|c|c|c|c|c|c|c|}
\hline \multirow[t]{2}{*}{ Item } & \multirow{2}{*}{$\begin{array}{l}\text { Incubation } \\
\text { period }(h)\end{array}$} & \multicolumn{5}{|c|}{ Molar percentages of acids } & \multirow[t]{2}{*}{$A: P$} & \multirow[t]{2}{*}{$p H$} & \multirow{2}{*}{$\begin{array}{l}\mathrm{NH}_{3}-\mathrm{N} \\
(\mathrm{mg} / \mathrm{dl})\end{array}$} \\
\hline & & Acetate & Prop & $\mathrm{n}$-Buty & i-Valerate & $\mathrm{n}$-Valerate & & & \\
\hline \multirow[t]{4}{*}{ Rs } & 12 & $52.6^{b}$ & $19.4^{b}$ & 15.4 & 5.9 & $3.0^{\mathrm{a}}$ & 2.9 & $6.6^{c}$ & $32.3^{a}$ \\
\hline & 24 & $56.7^{\mathrm{c}}$ & $23.1^{b}$ & $12.6^{b}$ & $5.8^{\mathrm{c}}$ & 1.7 & 2.5 & $6.5^{\mathrm{b}}$ & $29.2^{\mathrm{a}}$ \\
\hline & 48 & $51.8^{\mathrm{d}}$ & $24.2^{b}$ & $13.1^{b}$ & $6.5^{\mathrm{d}}$ & - & 2.1 & $6.5^{c}$ & $29.8^{a}$ \\
\hline & 72 & $51.6^{c}$ & $28.9^{b}$ & $12.4^{b}$ & $4.6^{c}$ & $2.6^{\mathrm{a}}$ & 1.8 & $6.5^{c}$ & $24.2^{a}$ \\
\hline \multirow[t]{4}{*}{ Sct } & 12 & $48.8^{a}$ & $26.7^{c}$ & 14.8 & 5.3 & $3.0^{\mathrm{a}}$ & 1.8 & $6.4^{\mathrm{a}}$ & $35.2^{a}$ \\
\hline & 24 & $48.8^{a}$ & $35.6^{d}$ & $11.2^{\mathrm{b}}$ & $3.4^{\mathrm{a}}$ & 1.6 & 1.4 & $6.3^{\mathrm{a}}$ & $26.3^{a}$ \\
\hline & 48 & $40.7^{a}$ & $41.7^{\mathrm{d}}$ & $12.1^{b}$ & $2.1^{\mathrm{a}}$ & - & 1.0 & $5.8^{\mathrm{a}}$ & $32.5^{\mathrm{a}}$ \\
\hline & 72 & $39.8^{a}$ & $44.6^{d}$ & $9.8^{a}$ & $2.3^{a}$ & $3.4^{b}$ & 0.9 & $5.5^{\mathrm{a}}$ & $29.8^{a}$ \\
\hline \multirow[t]{4}{*}{ At } & 12 & $53.7^{\mathrm{b}}$ & $20.8^{b}$ & 14.0 & 5.5 & $3.5^{\mathrm{a}}$ & 2.6 & $6.5^{\mathrm{b}}$ & $50.4^{b}$ \\
\hline & 24 & $58.0^{c}$ & $24.2^{b}$ & $11.3^{\mathrm{b}}$ & $4.5^{b}$ & 1.6 & 2.4 & $6.4^{\mathrm{b}}$ & $48.9^{b}$ \\
\hline & 48 & $53.3^{e}$ & $26.3^{b c}$ & $12.8^{\mathrm{b}}$ & $5.5^{\mathrm{b}}$ & - & 2.0 & $6.3^{b}$ & $69.2^{\mathrm{c}}$ \\
\hline & 72 & $51.9 \mathrm{c}$ & $31.2^{c}$ & $10.7^{\mathrm{ab}}$ & $3.9^{b}$ & $2.3^{a}$ & 1.7 & $6.2^{\mathrm{b}}$ & $62.3^{c}$ \\
\hline \multirow[t]{4}{*}{ Athp } & 12 & $51.5^{\mathrm{ab}}$ & $19.5^{\mathrm{b}}$ & 15.3 & 6.3 & $3.7^{a}$ & 2.6 & $6.5^{\mathrm{b}}$ & $34.3^{a}$ \\
\hline & 24 & $53.3^{b}$ & $30.2^{c}$ & $10.7^{a}$ & $4.1^{a b}$ & 1.3 & 1.8 & $6.5^{\mathrm{b}}$ & $32.5^{a}$ \\
\hline & 48 & $50.9^{c}$ & $28.3^{c}$ & $11.3^{a}$ & $6.0^{c}$ & - & 1.8 & $6.4^{b}$ & $43.2^{\mathrm{b}}$ \\
\hline & 72 & $51.5^{\mathrm{c}}$ & $31.3^{\mathrm{c}}$ & $10.9^{a b}$ & $3.9^{b}$ & $2.5^{\mathrm{a}}$ & 1.6 & $6.3^{b}$ & $46.1^{b}$ \\
\hline \multirow[t]{4}{*}{ Blank } & 12 & $49.1^{a}$ & $16.0^{\mathrm{a}}$ & 13.7 & 8.9 & $6.8^{b}$ & 3.1 & $6.5^{\mathrm{b}}$ & $58.0^{\circ}$ \\
\hline & 24 & $68.4^{d}$ & $13.3^{a}$ & $11.3^{b}$ & $9.7^{d}$ & - & 5.1 & $6.5^{\mathrm{b}}$ & $53.0^{\mathrm{C}}$ \\
\hline & 48 & $47.5^{b}$ & $17.4^{a}$ & $14.6^{\mathrm{c}}$ & $11.2^{\mathrm{e}}$ & - & 2.7 & $6.6^{d}$ & $85.2^{\mathrm{d}}$ \\
\hline & 72 & $50.6^{b}$ & $17.3^{a}$ & $16.9^{c}$ & $8.3^{\mathrm{d}}$ & $3.8^{\mathrm{c}}$ & 2.9 & $6.7^{c}$ & $83.0^{d}$ \\
\hline
\end{tabular}

- The values are means of 4 observations; means within the same column and period with different letters differ (DMRT, $P<0.01$ ); A:P: acetate/propionate ratio; Prop: propionate; $n$-Buty: n-butyrate.

wheat straw (Lewis et al, 1988). On the other hand, using $\mathrm{NaOH}$ as the alkali in the alkaline hydrogen peroxide treatment decreased lignin content about 5 percentage units (Lewis et al, 1988). However, in the present experiment, this response was not observed probably due to $\mathrm{NH}_{4} \mathrm{OH}$ being a weaker base than $\mathrm{NaOH}$.

The increased degradation of At was expected as has been reported in previous studies (Graham and Aman, 1984; Cann et al, 1991). The higher digestibilities of At and Sct compared with Athp and Rs can be explained by the decrease in lignin content, which is one of the major limiting factors of digestion, in At and Sct. The decreases in lignin in At and Sct agree with findings reported elsewhere (Brown et al, 1987; Cann et al, 1993b). The fact that the degradation of Sct during the 48-h and $72-h$ incubations was $17 \%$ and $12 \%$ units, respectively, above that of At could be explained by the further decrease in lignin content of Sct, and supports the previous assumption that the decrease in the intake of Sct by sheep may not be due to micro- 
Table IV. Fermentation products, $\mathrm{pH}$ and $\mathrm{NH}_{3}-\mathrm{N}$ concentrations of treated and untreated rice straw with whole rumen fluid (WRF) in the presence of cycloheximide (bacteria + protozoa: $\mathrm{B}+\mathrm{P}$ ) in vitro*.

\begin{tabular}{|c|c|c|c|c|c|c|c|c|c|}
\hline \multirow[t]{2}{*}{ Item } & \multirow{2}{*}{$\begin{array}{l}\text { Incubation } \\
\text { period }(h)\end{array}$} & \multicolumn{5}{|c|}{ Molar percentages of acids } & \multirow[t]{2}{*}{$A: P$} & \multirow[t]{2}{*}{$p H$} & \multirow{2}{*}{$\begin{array}{l}\mathrm{NH}_{3}-\mathrm{N} \\
(\mathrm{mg} / \mathrm{dl})\end{array}$} \\
\hline & & Acetate & Prop & $\mathrm{n}-$ Buty & i-Valerate & $\mathrm{n}$-Valerate & & & \\
\hline \multirow[t]{4}{*}{ Rs } & 12 & $57.6^{b}$ & $26.4^{a}$ & 10.2 & 3.6 & 2.2 & 2.2 & 6.6 & $13.7^{a}$ \\
\hline & 24 & $53.6^{b}$ & $30.3^{b}$ & $9.4^{b}$ & $4.5^{\mathrm{b}}$ & 2.2 & 1.8 & $6.4^{\mathrm{b}}$ & $18.0^{a}$ \\
\hline & 48 & $53.1^{\mathrm{b}}$ & $30.0^{b}$ & $10.5^{b}$ & $4.0^{c}$ & 2.4 & 1.8 & $6.1^{\mathrm{b}}$ & $32.6^{\mathrm{b}}$ \\
\hline & 72 & $50.8^{\mathrm{b}}$ & $32.8^{\mathrm{b}}$ & $9.5^{\mathrm{b}}$ & $4.7^{c}$ & $2.3^{a}$ & 1.6 & $6.3^{\mathrm{b}}$ & $41.7^{\mathrm{b}}$ \\
\hline \multirow[t]{4}{*}{ Sct } & 12 & $50.3^{a}$ & $32.7^{b}$ & 10.4 & 3.8 & 1.9 & 1.5 & 6.6 & $10.2^{a}$ \\
\hline & 24 & $45.9^{a}$ & $41.3^{d}$ & $8.1^{a}$ & $2.8^{a}$ & 1.8 & 1.1 & $6.2^{\mathrm{a}}$ & $12.2^{a}$ \\
\hline & 48 & $42.3^{a}$ & $43.7^{d}$ & $9.9^{a}$ & $2.1^{\mathrm{a}}$ & 1.9 & 1.0 & $5.8^{\mathrm{a}}$ & $26.3^{a}$ \\
\hline & 72 & $37.7^{a}$ & $48.0^{\mathrm{c}}$ & $9.8^{\mathrm{C}}$ & $2.4^{\mathrm{a}}$ & $2.1^{\mathrm{a}}$ & 0.8 & $5.7^{a}$ & $33.2^{\mathrm{a}}$ \\
\hline \multirow[t]{4}{*}{ At } & 12 & $58.3^{b}$ & $27.1^{a}$ & 9.5 & 3.4 & 1.6 & 2.2 & 6.6 & $27.8^{b}$ \\
\hline & 24 & $58.2^{c}$ & $29.4^{b}$ & $8.0^{\mathrm{a}}$ & $2.8^{\mathrm{a}}$ & 1.6 & 2.0 & $6.3^{b}$ & $26.5^{b}$ \\
\hline & 48 & $55.1^{\mathrm{C}}$ & $29.7^{b}$ & $9.9^{a}$ & $3.2^{b}$ & 2.2 & 1.9 & $6.1^{b}$ & $45.0^{d}$ \\
\hline & 72 & $51.4^{\mathrm{b}}$ & $33.2^{\mathrm{b}}$ & $8.9^{a}$ & $4.5^{c}$ & $2.1^{\mathrm{a}}$ & 1.6 & $6.4^{b}$ & $54.1^{c}$ \\
\hline \multirow[t]{4}{*}{ Athp } & 12 & $57.5^{b}$ & $26.7^{a}$ & 10.3 & 3.6 & 2.0 & 2.2 & 6.5 & $12.9^{a}$ \\
\hline & 24 & $54.4^{b}$ & $32.7^{c}$ & $8.0^{a}$ & $3.1^{\mathrm{a}}$ & 1.7 & 1.7 & $6.3^{b}$ & $15.5^{a}$ \\
\hline & 48 & $53.7^{b}$ & $31.4^{c}$ & $9.7^{\mathrm{a}}$ & $3.1^{\mathrm{b}}$ & 2.1 & 1.7 & $6.2^{\mathrm{b}}$ & $32.1^{\mathrm{b}}$ \\
\hline & 72 & $50.7^{b}$ & $34.5^{\mathrm{b}}$ & $9.0^{a b}$ & $3.9^{\mathrm{b}}$ & $1.8^{a}$ & 1.5 & $6.2^{\mathrm{b}}$ & $41.5^{b}$ \\
\hline \multirow[t]{4}{*}{ Blank } & 12 & $56.7^{b}$ & $26.2^{\mathrm{a}}$ & 10.4 & 4.6 & 1.9 & 2.2 & 6.6 & $26.2^{b}$ \\
\hline & 24 & $57.1^{\mathrm{c}}$ & $18.9^{a}$ & $9.8^{b}$ & $7.0^{\mathrm{b}}$ & 1.8 & 3.0 & $6.7^{c}$ & $33.3^{c}$ \\
\hline & 48 & $52.7^{b}$ & $24.7^{a}$ & $13.6^{\mathrm{C}}$ & $6.6^{\mathrm{d}}$ & 2.7 & 2.2 & $6.5^{c}$ & $38.7^{c}$ \\
\hline & 72 & $52.0^{b}$ & $21.7^{a}$ & $11.6^{d}$ & $8.7^{d}$ & $3.1^{b}$ & 2.4 & $6.7^{c}$ & $39.9^{b}$ \\
\hline
\end{tabular}

- The values are means of 4 observations; means within the same column and period with different letters differ (DMRT, $P<0.01$ ); A:P: acetate/propionate ratio; Prop: propionate; $n$-Buty: n-butyrate.

bial factors but rather to animal factors such as reduced palatability (Cann et al, $1993 b)$. The rumen is a complex ecological system in which the numerous microorganisms present are inter-dependent. The removal of the microbes from their natural habitat is likely to have adverse effects on those organisms most susceptible to micro-environmental changes. That the degradation of the straws in the in sacco experiment is higher than that for the in vitro studies, may thus be attributed to a decrease in the efficiency of the microbial in- ter-relationship in the in vitro environment. The effect was more pronounced in the more easily digestible straw (At and Sct).

The use of cycloheximide in the present experiment to suppress fungal activity resulted in higher propionate proportions with decreasing butyrate proportions (tables III and IV). The significantly higher proportion of propionate resulting from Sct fermentation was shown to be due to the fungicidal effect of Sct (Cann et al, 1993b; Elliot et al, 1987). The A:P ratio of less than 1 is rarely encountered during the fer- 
mentation of fibrous materials (Miron and Ben-Ghedalia, 1987; Cameron et al, 1991; Cann et al, 1991). The suppression of the anaerobic fungi leading to a higher propionate proportion at the expense of acetate proportion has been demonstrated by using other antifungal substances, namely polyoxin D (Cann et al, 1993a,b) and monensin (Elliot et al, 1987). The results of the present experiment, therefore, show that the suppression of rumen fungi may decrease the microbial degradation of fibrous materials and will surely shift the fermen-tation toward increased production of propionate while suppressing the acetate pathway. This view is consistent with the finding that rumen fungi produce acetate but not butyrate (Mountfort and Asher, 1985). Rumen methane is mainly produced by the reduction of $\mathrm{CO}_{2}$ with hydrogen gas. The carbon dioxide originates from the conversion of pyruvic acid to acetate. Methane production is a by-product of high energy value. A decrease in the production of acetate will, therefore, minimize this waste in the fermentation process. In addition, propionate is more efficiently used by tissues with 17-18 mol ATP resulting from the oxidation of propionate while only $10 \mathrm{~mol}$ ATP are produced from the oxidation of acetate. Cycloheximide, which totally inhibited fungal growth, is a protein synthesis inhibitor (Pelczar et al, 1977). Windham and Akin (1984) indicated that some protozoa, especially the holotrichs, retain some activity in the presence of this antibiotic. The entodiniomorphid and holotrichs found in the rumen samples used in the present experiment produce butyrate as an end-product of metabolism (Williams and Coleman, 1988). The decrease in butyrate proportion during $(B+P)$ fermentation may be due to the effect of cycloheximide on the rumen protozoa. In addition, this limited suppressive effect of the antibiotic on rumen protozoa may have influenced the extent of degra- dation of plant material by the rumen microorganisms (fig $2 b$ ). Whereas the decrease in the degradation during incubation with $\mathrm{B}+\mathrm{P}$ cannot be entirely attributed to fungal suppression, the addition of this antibiotic (cycloheximide) resulted in a fermentation pattern sirnilar to that reported for other antifungal substances (Elliot et al, 1987; Cann et al, 1993a,b). The effect of cycloheximide inclusion resulting in lower digestibilities during the 48-h and 72-h incubations also throws light on the importance of rumen fungi during the later stages of fermentation when more refractory materials remain in the fermentation system.

The significantly low $\mathrm{pH}$ (table III and IV) during Sct fermentation was inconsistent with the results in vivo with sheep, where the ruminal $\mathrm{pH}$ of the animals being fed Sct was between 6.8 and 6.9 (Elliot et al, 1987; Cann et al, 1993b). This observation is explained by the buffering ability of the rumen ecosystem.

\section{REFERENCES}

Brown WF, Philips JD, Jones DB (1987) Ammoniation or cane molasses supplementation of low quality forages. I Anim Sci 64, 12051214

Cameron MG, Cameron MR, Fahey JC Jr, Clark JH, Berger LL, Merchen NR (1991) Effects of treating oat hulls with alkaline hydrogen peroxide on intake and digestion by midlactation dairy cows. J Dairy Sci 74, 177-189

Cann IKO, Kobayashi Y, Wakita M, Hoshino S (1991) Digestion properties of ammoniated rice straw in the rumen and lower tract of sheep. Anim Feed Sci Technol 35, 55-68

Cann IKO, Kobayashi Y, Onoda A, Wakita M, Hoshino $S$ (1993a) Effects of some ionophore antibiotics and polyoxins on the growth of anaerobic rumen fungi. I App/ Bacteriol $74,127-133$

Cann IKO, Kobayashi Y, Wakita M, Hoshino S (1993b) Fungal suppression and its effects 
on some ruminal parameters. Anim Sci Technol (Jpn) 64, 233-238

Cann IKO, Kobayashi Y, Wakita M, Hoshino S (1993c) Effects of ammoniated rice straw feeding on microbes and their fermentation end-products in the rumen and caecum of sheep. AJAS 6, 61-72

Duncan DB (1955) Multiple range and multiple $F$ tests. Biometrics 11, 1-42

Elliot R, Ash AJ, Calderon-Cortes F, Norton BW, Bauchop T (1987) The influence of anaerobic fungi on rumen volatile fatty acid concentration in vivo. J Agric Sci (Camb) 109, 13-17

Graham H, Aman P (1984) A comparison between degradation in vitro and in sacco of constituents of untreated and ammoniatreated barley straw. Anim Feed Sci Technol 10, 199-211

Lewis SM, Montgomeny L, Garleb, Berger LL, Fahey GC Jr (1988) Effects of alkaline hydrogen peroxide treatment on in vitro degradation of cellulosic substrates by mixed ruminal micro- organisms and Bacteroides succinogenes S85. Appl Environ Microbiol 54, 1163-1169

McDougall El (1948) Studies on ruminant saliva. I. The composition and output of sheep saliva. Biochem J 43, 99-109

Miron J, Ben-Ghedalia D (1987) Nutritional implications associated with increasing the fermentability of straw by chemical and enzymatic treatments. J Dairy Sci 70, 1864-1875

Mountfort DO, Asher RA (1985) Production and regulation of cellulase by two strains of the rumen anaerobic fungus Neocallimastix frontalis. Appl Environ Microbio/ 49, 1314-1322

Pelczar MJ Jr, Reid RD, Chan ECS (1977) Microbiology (4th ed) McGraw-Hill Book Co, New York, p 480

Williams AG, Coleman GS (1988) The rumen protozoa. In: The Rumen Microbial Ecosystem (PN Hobson, ed) Elsevier Science Publishers, New York, 77-128

Windham WR, Akin DE (1984) Rumen fungi and fiber degradation. Appl Environ Microbiol 4, 473-476 